\title{
Evaluation of a Swine Line Developed at the Agricultural Experiment Station of the University of Puerto Rico
}

\author{
Ismael Carlo and C. L. Arcelay ${ }^{1}$
}

INTRODUCTION

This Agricultural Experiment Station has developed a line of swine which is the result of a series of crosses between females of the Duroc breed and an English Large Black Landrace boar, and the subsequent selection. ${ }^{2}$

In order to compare its potentialities as a good stock for the Puerto Rican farmer with those of imported breeds of swine, a number of pigs from three popular breeds in the United States were imported by the Station. Animals of these three breeds have been frequently imported by local farmers in an effort to improve the quality and performance of their pigs. The pigs imported by the Station were from the Duroc, the Hampshire, and the Yorkshire breeds. All pigs were purebred registered animals from duly registered herds.

The comparison was made based on preweaning and postweaning performance, and slaughtering data of the progeny of the imported pigs and that of the Station line. The progeny used was that obtained from the first two consecutive farrowings. The results of the comparison are presented herein.

\section{PROCEDURE}

Twelve gilts of the Hampshire breed, twelve of the Yorkshire breed, and the same number of the $3 / 4$ Duroc X $1 / 4$ English Large Black line developed at the Station, and 11 gilts of the Duroc breed were mated to purebred boars of their respective breeds in order to obtain progeny of these animals. This progeny was used to evaluate and compare their performance.

The comparison was based on data obtained from two consecutive farrowings. Since not all the gilts farrowed twice, the number of litters used was not the same for all breeds. The evaluation of the preweaning characteristics was made by comparing the number of pigs at farrowing, at 21 days, and at weaning age, together with the total weights of the litters in each of these periods. The postweaning performance was evaluated by using the

${ }^{1}$ Animal Husbandman and Professor, and Professor and Animal Husbandman, Lajas Substation, Lajas, P. R., Agricultural Experiment Station and College of Agriculture and Mechanic Arts, University of Puerto Rico, respectively, Río Piedras and Mayagüez, P.R.

${ }^{2}$ Carlo, I. and C. L. Arcelay, The development of a line of swine for Puerto Rico, Bull. 193, Agr. Exp. Sta., Univ. P. R., May 1965. 
rate of gain and the feed efficiency of the pigs from weaning to 154 days of age. At this age back-fat measurements were taken on all animals. These measurements were corrected to 200 pounds live weight.

All the pigs farrowed were ear-notched and weighed shortly after farrowing. Heat lamps were used in the farrowing pens during the first 15 days of the pig's life. All of the pigs received an iron injection 2 days after birth.

The piglets began receiving a starter ration after 15 days of age. They continued to receive the same feed until weaning at 56 days of age. The ration was self-fed.

The pigs were weighed at 21 and at 56 days of age. All males to be used as barrows in the feeding trial, were castrated at about 25 to 30 days of age. The pigs were vaccinated against cholera at about 40 to 45 days of age.

The sows were brought to the farrowing quarters about 1 week before they were due. They remained there until the pigs were weaned at 56 days. Sawdust or bagasse was used in the farrowing pens during the first 21 days of the lactation period. Each pen had a $10 \times 10$-foot concrete floor, and was cyclone-fenced on the sides with aluminium roofing, and equipped with automatic waterers. For the postweaning performance, the tests were conducted by taking a sample of four or five pigs from each litter that went into a feeding trial. The litter was, therefore, represented by one boar, two barrows and two gilts. In some cases a boar from a particular litter was not used, leaving only four animals representing that litter. The barrows and gilts were group-fed in pens with automatic self-feeders. The boars were also group-fed. Each group of boars, as in the case of the barrows and gilts, consisted of four pigs. The pigs were selected by weight from the litters, taking the heavier pigs if they were free from physical defects.

Each group of pigs was weighed every 28 days and the feed consumed during each period recorded. Each group was placed in pens similar to those used for the farrowing females. They were provided with self-feeders and automatic waterers.

The pigs received a concentrate ration suited for growing fattening pigs, fed ad libitum. The same ration was used throughout the two experiments. No other type of feed was used during both trials. The boars and gilts were live-probed at 154 days of age for back-fat thickness. This age marked the termination of each trial. The rate of gain and the feed efficiency were calculated at the end of the feeding period. The barrows were slaughtered and measurements were taken on the carcasses.

All data were submitted to analysis of variance and, in cases where the F's were significant, a Duncan Multiple Test was carried out to determine significance among the means. ${ }^{3}$

${ }^{3}$ Steel, Robert, G.D., and Torrie, James H., Principles and Procedures of Statistics, McGraw-Hill Book Co., New York, N. Y., 1960. 


\section{RESULTS}

\section{PREWEANING PERFORMANCE}

The preweaning performance of the progeny of all the sows in this trial is shown in table 1 . Tables 2,3 , and 4 show the analysis of variance and the corresponding Duncan Multiple Test for number of pigs farrowed and

TABLE 1.-Preweaning performance of the sows of the Duroc, Yorkshire, and Hampshire breeds and the $3 / 4$ Duroc $X 1 / 4$ English large black Landrace line

\begin{tabular}{|c|c|c|c|c|c|c|c|}
\hline \multirow{2}{*}{ Breed } & \multirow{2}{*}{ Litters } & \multicolumn{3}{|c|}{ Average pigs per litter- } & \multicolumn{3}{|c|}{$\begin{array}{l}\text { Actual average weight } \\
\text { per pig at }-\end{array}$} \\
\hline & & Farrowed & $\begin{array}{l}\text { At } 21 \\
\text { days }\end{array}$ & $\begin{array}{c}\text { At } \\
\text { weaning }\end{array}$ & Birth & 21 days & weaning \\
\hline & Number & Number & Number & Number & Pounds & Pounds & Pounds \\
\hline Duroc & 20 & 9.50 & 6.95 & 6.58 & 3.04 & 10.43 & 31.83 \\
\hline Yorkshire & 16 & 12.12 & 10.00 & 9.62 & 2.93 & 9.62 & 27.04 \\
\hline Hampshire & 24 & 10.20 & 7.30 & 6.95 & 2.93 & 11.72 & 30.62 \\
\hline 3/4 Duroc X $1 / 4$ Landrace & 23 & 10.39 & 8.52 & 8.39 & 2.76 & 10.54 & 32.86 \\
\hline
\end{tabular}

TABLE 2.-Analysis of variance for number of pigs per litter farrowed by the sows of the different breeds

\begin{tabular}{c|c|c|c|c}
\hline Source of variation & D/F & S. S. & M. S. & F \\
\cline { 2 - 3 } Breeds & 3 & $\begin{array}{r}64.41 \\
524.19\end{array}$ & $\begin{array}{r}21.47 \\
6.64\end{array}$ & $3.23^{1}$ \\
Error & 79 & 588.60 & & \\
\cline { 2 - 3 } Total & 82 & & \\
\hline
\end{tabular}

1 Significant at 5-percent level.

Duncan Multiple Test:

Yorkshire 3/4 Duroc X 1/4 Landrace line Hampshire Duroc
12.12
10.39
10.20
9.50

number of pigs alive at 21 days and at weaning time per litter. The sows of the Yorkshire breed were superior (significant at 5-percent level) to the sows of the other breeds in number of pigs farrowed. There was no significant difference among the sows of the other breeds. The Yorkshire sows were also superior to all the other sows in number of pigs alive at 21 and at 56 days of age at the 1-percent level. No significant difference was found among the other breeds. There was no significant difference among the number of pigs weaned by the Yorkshire sows and the $3 / 4$ Duroc X $1 / 4$ English Large Black Landrace sows at the 5-percent level. They were both 
superior to the sows of the Hampshire and Duroc breeds, between which there was no significant difference.

A correlation analysis was performed to determine whether the number

TABLE 3.-Analysis of variance for number of pigs per litter at 21 days in different breeds

\begin{tabular}{c|c|c|c|c}
\hline Source of variation & D/F & S. S. & M. S. & F \\
\cline { 1 - 3 } Breeds & 3 & $\begin{array}{r}108.51 \\
499.29\end{array}$ & $\begin{array}{r}36.17 \\
6.48\end{array}$ & $5.58^{1}$ \\
Error & 77 & & \\
\cline { 2 - 4 } Total & 80 & 607.80 & & \\
\hline
\end{tabular}

${ }^{1}$ Significant at 1-percent level.

Duncan Multiple Test:

At 1-percent level
Yorkshire
$3 / 4$ Duroc X $1 / 4$ Landrace line
Hampshire
Duroc
10.00
8.52
7.14
6.95

At 5-percent level
Yorkshire
$3 / 4$ Duroc X $1 / 4$ Landrace line
Hampshire
Duroc
10.00
8.52
7.14
6.95

TABLE 4.-Analysis of variance for number of pigs weaned per litter of different breeds

\begin{tabular}{c|c|c|c|c}
\hline Source of variation & D/F & S. S. & M. S. & F \\
\cline { 1 - 2 } Breeds & 3 & $\begin{array}{r}110.75 \\
505.79\end{array}$ & $\begin{array}{r}36.92 \\
6.56\end{array}$ & $5.62^{1}$ \\
Error & 77 & & \\
\cline { 2 - 4 } Total & 80 & 616.54 & & \\
\hline
\end{tabular}

1 Significant at 1-percent level.

Duncan Multiple Test:

At 1-percent level
Yorkshire
3/4 Duroc X 1/4 Landrace line
Hampshire
Duroc
9.62
8.39
6.72
6.70

At 5-percent level
Yorkshire
3/4 Duroc X 1/4 Landrace line
Hampshire
Duroc
9.62
8.39
6.72
6.70

of pigs in the litter had any effect upon their weight at different ages. Correlation coefficients of $+0.84,+0.88$, and +0.84 between these two characteristics were found at farrowing, at 21 days, and at weaning time at 56 days, respectively. All the correlations were highly significant. 
Because of this, the regression coefficients for the various age groups were worked out, and using the corresponding regression equation, the weights of the pigs were corrected to account for the influence of the size of the litters. Both correlation and regression coefficients are shown in table 5 and the corrected weight of the pigs in table 6 .

TABLE 5.-Correlation and regression coefficients for number of pigs and weights at different ages

\begin{tabular}{c|c|c}
\hline Pigs- & Correlation coefficient $r^{\prime}$ & Regression coefficient $b$ \\
\cline { 2 - 3 } Farrowed & 0.84 & 2.43 \\
At 21 days & .88 & 9.24 \\
At weaning & .84 & 26.06 \\
\hline
\end{tabular}

${ }^{1}$ All correlation coefficients were highly significant $(\mathrm{P}<.01)$.

TABLE 6.-Average weight (pounds) per pig at different ages corrected for number of pigs per litter

\begin{tabular}{l|r|r|c}
\hline \multicolumn{1}{c|}{ Breed } & At farrowing & At 21 days & At weaning \\
\cline { 1 - 1 } Duroc & 3.29 & 11.99 & 36.68 \\
Yorkshire & 2.60 & 8.00 & 21.95 \\
Hampshire & 2.99 & 12.04 & 34.29 \\
3/4 Duroc X 1/4 Landrace & 2.78 & 10.12 & 31.34 \\
\hline
\end{tabular}

TABLE 7.-Analysis of variance for corrected total farrowing weights per litter of different breeds of swine

\begin{tabular}{c|r|r|r|r}
\hline Source of variation & D/F & S. S. & M. S. & F \\
\cline { 2 - 4 } Breed & 3 & 86.46 & 28.82 & $1.66^{1}$ \\
Error & 79 & $1,368.57$ & 17.32 & \\
\cline { 2 - 4 } Total & 82 & $1,455.03$ & & \\
\hline
\end{tabular}

${ }^{1}$ Not significant.

The analysis of variance for the differences in corrected weight of the pigs at farrowing and at 21 days of age is shown in tables 7 and 8 . There were no significant differences in these weights attributable to the breed of the sow. The differences were significant between breeds at weaning time, as shown in table 9. When subjected to the Duncan Multiple Test at the 5-percent level, the Yorkshire pigs were significantly lighter in weight to the pigs of the other breeds, but at the 1-percent level, the Yorkshire were 
only significantly different from the pigs of the $3 / 4$ Duroc X $1 / 4$ English Large Black Landrace line.

\section{POSTWEANING PERFORMANCE}

The postweaning performance of the pigs on the feeding trials included in this study is shown in table 10. The analysis of variance for the rate of

TABLE 8.-Analysis of variance for corrected total at 21 days of weight per litter of different breeds of swine

\begin{tabular}{c|r|r|r|r}
\hline Source of variation & D/F & S. S. & M. S. & F \\
\cline { 2 - 3 } Breeds & 3 & 648.49 & 216.16 & $1.40^{1}$ \\
Error & 77 & $11,926.20$ & 154.88 & \\
\cline { 2 - 4 } Total & 80 & $12,574.69$ & & \\
\hline
\end{tabular}

${ }^{1}$ Not significant.

TABLE 9.-Analysis of variance for corrected total weaning weight per litter of different breeds of swine

\begin{tabular}{c|c|c|c|c}
\hline Source of variation & D/F & S. S. & M. S. & F \\
\cline { 2 - 3 } Breed & 3 & $2,5451.33$ & $8,483.78$ & $4.96^{1}$ \\
Error & 77 & $13,1677.16$ & $1,710.09$ & \\
\cline { 2 - 4 } Total & 80 & $15,7128.49$ & & \\
\hline
\end{tabular}

${ }_{1}^{1}$ Significant at 1-percent level.

Duncan Multiple Test:

At 1-percent level

$\begin{array}{cccc}3 / 4 \text { Duroc X 1/4 Landrace line } & \text { Duroc } & \text { Hampshire } & \text { Yorkshire } \\ 263 & 241 & 238 & 211\end{array}$

At 5-percent level

$\begin{array}{cccc}3 / 4 \text { Duroc X 1/4 Landrace line } & \text { Duroc } & \text { Hampshire } & \text { Yorkshire } \\ 263 & 241 & 238 & 211\end{array}$

gain of the barrows, the gilts and the boars of the different breeds are shown in tables 11,12 , and 13 respectively. There was no significant difference in the rate of gain between barrows and boars due to breed.

In the gilts there was no significant difference in rate of gain attributable to breed. At the 5-percent level, there was no significant difference between the gilts of the Station line and those of the Duroc breed, but the gilts of the Station line were superior to those of the Yorkshire and Hampshire 
breeds. There was no significant difference between the Duroc and the Yorkshire gilts, but the Durocs were superior to the Hampshire gilts.

At the 1-percent level, the differences in four of the Station gilts were not significant as to the rate of gain of the Duroc or Yorkshire gilts, but were

TABLE 10.-Average rate of gain, back-fat thickness, and feed efficiency for different breeds of swine, by sex

\begin{tabular}{|c|c|c|c|c|}
\hline Breed & Sex & Rate of gain & $\begin{array}{l}\text { Back-fat } \\
\text { thickness }\end{array}$ & $\begin{array}{c}\text { Feed } \\
\text { efficiency }\end{array}$ \\
\hline Duroc & $\begin{array}{l}\text { Boars } \\
\text { Barrows } \\
\text { Gilts } \\
\text { Boars }\end{array}$ & $\begin{array}{c}L b . \\
1.770 \\
1.738 \\
1.686 \\
1.694\end{array}$ & $\begin{array}{c}\text { In. } \\
1.28 \\
1.27 \\
1.43 \\
1.28\end{array}$ & $\begin{array}{c}b . \\
338 \\
360 \\
360 \\
338\end{array}$ \\
\hline Yorkshire & $\begin{array}{l}\text { Barrows } \\
\text { Gilts } \\
\text { Boars }\end{array}$ & $\begin{array}{l}1.699 \\
1.632 \\
1.734\end{array}$ & $\begin{array}{l}1.45 \\
1.31 \\
1.18\end{array}$ & $\begin{array}{l}345 \\
345 \\
346\end{array}$ \\
\hline Hampshire & $\begin{array}{l}\text { Barrows } \\
\text { Gilts } \\
\text { Boars }\end{array}$ & $\begin{array}{l}1.674 \\
1.582 \\
1.829\end{array}$ & $\begin{array}{l}1.49 \\
1.26 \\
1.36\end{array}$ & $\begin{array}{l}400 \\
400 \\
336\end{array}$ \\
\hline $3 / 4$ Duroc X Landrace & $\begin{array}{l}\text { Barrows } \\
\text { Gilts }\end{array}$ & $\begin{array}{l}1.794 \\
1.721\end{array}$ & $\begin{array}{l}1.55 \\
1.50\end{array}$ & $\begin{array}{l}366 \\
366\end{array}$ \\
\hline
\end{tabular}

TABLE 11.-Analysis of variance for the rate of gain of barrows of different breeds of swine

\begin{tabular}{c|r|r|r|c}
\hline Source of variation & D/F & S. S. & M. S. & F \\
\hline Breed & 3 & $\begin{aligned} \text { D.2389 } \\
\text { Error }\end{aligned}$ & $\begin{array}{r}0.0796 \\
.0416\end{array}$ & $1.91^{1}$ \\
Total & 106 & 4.5805 & & \\
\hline
\end{tabular}

${ }_{1}$ Not significant.

to that of the Hampshire breed. There was no significant difference in rate of gain attributable to breed among the gilts of the three imported breeds.

As the pigs were group-fed, the feed efficiency was analyzed for groups. The analyses of variance for feed efficiency for the gilts and the barrows and for the boars of the different breeds are presented in tables 14 and 15 .

There was a highly significant difference in feed efficiency of the barrows and the gilts related to breed. The Duncan Multiple Test showed that either at the 1- or the 5-percent level, the efficiency of the pigs of the York- 
TABLE 12.-Analysis of variance for the rate of gain of gilis of different breeds of swine

\begin{tabular}{c|r|r|r|r}
\hline Source of variation & D/F & S. S. & M. S. & F \\
\cline { 2 - 4 } Breed & 3 & 0.3552 & 0.1117 & $4.28^{1}$ \\
Error & 111 & 2.8972 & .0261 & \\
\cline { 2 - 4 } Total & 114 & 3.2324 & & \\
\hline
\end{tabular}

${ }^{1}$ Significant at 1 percent.

Duncan Multiple Test:

At 1 percent

$\begin{array}{cccc}3 / 4 \text { Duroc X } 1 / 4 \text { Lanrace } & \text { Duroc } & \text { Yorkshire } & \text { Hampshire } \\ 1.721 & 1.686 & 1.632 & 1.582\end{array}$

At 5 percent
1.721
1.686
1.632
1.582

TABLE 13.-Analysis of variance for the rate of gain of boars of different breeds of swine

\begin{tabular}{c|c|c|c|c}
\hline Source of variation & D/F & S. S. & M. S. & F \\
\cline { 2 - 4 } Breed & 3 & 0.0890 & 0.0296 & $0.68^{1}$ \\
Error & 32 & 1.3803 & .0431 & \\
\cline { 2 - 4 } Total & 35 & 1.4693 & & \\
\hline
\end{tabular}

${ }^{1}$ Not significant.

TABLe 14.-Analysis of variance for feed efficiency of barrows and gills of different breeds of swine

\begin{tabular}{c|c|c|c|c}
\hline Source of variation & D/F & S. S. & M. S. & F \\
\hline Breed & 3 & $2,2828.25$ & $7,609.42$ & $6.77^{1}$ \\
Error & 53 & $5,9562.63$ & $1,123.82$ & \\
\cline { 2 - 4 } Total & 56 & $8,2390.88$ & & \\
\hline
\end{tabular}

${ }_{1}^{1}$ Significant at 1 percent.

Duncan Multiple Test:

At 1-percent level

Yorkshire

Duroc

345

360

3/4 Duroc X 1/4 Landrace

366

Hampshire

400

At 5-percent level

Yorkshire

345

Duroc

3/4 Duroc X 1/4 Landrace

366

Hampshire

360

400 
shire and Duroc breeds, and those of the 3/4 Duroc X 1/4 English Large Black Landrace line, was not significantly different, but that they were all significantly better than the Hampshires. No significant difference due to breed was found in the boars for feed efficiency.

The analysis of variance for back-fat thickness of the barrows, the gilts, and the boars is shown in tables 16,17 , and 18 . There was a highly signifi-

TABLE 15.-Analysis of variance for feed efficiency of boars of different breeds

\begin{tabular}{c|c|c|c|c}
\hline Source of variation & D/F & S. S. & M. S. & F \\
\cline { 1 - 2 } Breed & 3 & 363.61 & 121.20 & $0.13^{1}$ \\
Error & 29 & $26,553.12$ & 915.62 & \\
\cline { 2 - 3 } Total & 32 & $26,916.73$ & & \\
\hline
\end{tabular}

${ }^{1}$ Not significant.

TABLE 16.-Analysis of variance for differences in back-fat thickness of barrows of different breeds of swine

\begin{tabular}{c|r|r|r|r}
\hline Source of variation & D/F & S. S. & M. S. & F \\
\cline { 1 - 2 } Breed & 3 & 1.3029 & 0.4343 & $11.25^{1}$ \\
Error & 105 & 4.0525 & .0386 & \\
\cline { 2 - 3 } Total & 108 & 5.3604 & & \\
\hline
\end{tabular}

${ }^{1}$ Significant at 1 percent.

Duncan Multiple Test:

At 1-percent level
Duroc
Yorkshire
Hampshire
3/4 Duroc X 1/4 Landrace
1.27
1.45
1.49
1.55

At 5-percent level

$\begin{array}{cccc}\text { Duroc } & \text { Yorkshire } & \text { Hampshire } & 3 / 4 \text { Duroc X } 1 / 4 \text { Landrace } \\ 1.27 & 1.45 & 1.49 & 1.55\end{array}$

cant difference attributable to breed when the back-fat thickness of the barrows was compared. The Duncan Multiple Test, either at the 1- or the 5-percent level, showed that there was no significant difference between the averages of the Yorkshires, the Hampshires, or the $3 / 4$ Duroc X $1 / 4$ English Large Black Landrace line, but that they were all higher in backfat thickness than the Duroc barrows.

There was a highly significant difference in the back-fat thickness of the gilts attributable to breed. When the Duncan Multiple Test was applied at the 1- or the 5-percent level it was found that the difference between the 
Hampshire and Yorkshire gilts was not significantly different, but both had a significantly lower back-fat than the gilts of the Duroc breed and the Station line. There was no significant difference from breed between the animals of these last two breeds.

TABLE 17.-Analysis of variance for back-fat thickness of guilts of different breeds of swine

\begin{tabular}{c|r|r|r|r}
\hline Source of variation & D/F & S. S. & M. S. & F \\
\hline Breed & 3 & 1.08 & 0.360 & $12.00^{1}$ \\
Error & 111 & 3.32 & .030 & \\
\cline { 2 - 4 } Total & 114 & 4.40 & & \\
\hline
\end{tabular}

${ }^{1}$ Significant at 1 percent. Duncan Multiple Test:

At 1-percent level

Hampshire

1.26

Yorkshire 1.31

At 5-percent level Hampshire 1.26

Yorkshire
1.31

Duroc

1.43

Duroc

1.43
3/4 Dur oc $1 / 4$ X Landrace 1.50

TABLE 18,-Analysis of variance for back-fat thickness of boars of different breeds of swine

\begin{tabular}{c|r|r|r|c}
\hline Source of variation & D/F & S. S. & M. S. & F \\
\hline Breed & 3 & 0.14 & 0.046 & $1.70^{1}$ \\
Error & 32 & .87 & .027 & \\
\cline { 2 - 4 } Total & 35 & 1.01 & & \\
\hline
\end{tabular}

${ }^{1}$ Not significant.

No significant difference was observed in the back-fat thickness of the boars attributable to the breed.

\section{SLAUGHTERING DATA}

There was no significant difference due to breed when the slaughtering and carcass weights, as well as the dressing percentage of the carcasses were compared. These data are shown in table 19.

The measurements and cutting results of the carcasses are presented in table 20. There was a highly significant difference in carcass length attributable to breed. The carcasses of the Yorkshire barrows were longer than 
those of any other breed. This difference was highly significant. There was no significant difference in length among the other three breeds. The analysis of variance and Duncan Multiple Test for the difference in carcass length are shown in table 21.

There was a highly significant difference in the loin-eye area attributable to the breed. The analysis of variance is presented in table 22 . The Duncan Multiple Test showed that when compared at the 1- and the 5-percent

TABLE 19.-Slaughter data for the barrows of the different breeds of swine

\begin{tabular}{l|c|c|c|c}
\hline \multicolumn{1}{c|}{ Breed } & Barrows & $\begin{array}{c}\text { Weight at } \\
\text { slaughter }^{1}\end{array}$ & $\begin{array}{c}\text { Carcass } \\
\text { weight }^{1}\end{array}$ & $\begin{array}{c}\text { Dressing } \\
\text { percentage }^{1}\end{array}$ \\
\cline { 2 - 2 } & Number & Lb. & Lb. & Percent \\
Hampshire & 25 & 209.68 & 156.34 & 72.17 \\
3/4 Duroc X 1/4 Landrace & 30 & 216.87 & 156.20 & 71.98 \\
Duroc & 29 & 204.93 & 152.05 & 74.09 \\
Yorkshire & 25 & 215.60 & 158.18 & 73.28 \\
\hline
\end{tabular}

${ }_{1}$ No significant differences in any of these 3 characteristics.

TABLE 20.-Some measurements and cutting results of the carcasses ${ }^{1}$ of swine of different breeds

\begin{tabular}{l|c|c|c|c|c|c}
\hline \multicolumn{1}{c|}{ Breed } & Carcasses & Length & Back-fat & $\begin{array}{c}\text { Loin eye } \\
\text { area }\end{array}$ & $\begin{array}{c}\text { Weight of 4 } \\
\text { principal } \\
\text { cuts }\end{array}$ & $\begin{array}{c}\text { Weight } \\
\text { of ham }\end{array}$ \\
\cline { 1 - 2 } & Number & In. & In. & Sq. in. & Lb. & Lb. \\
Hampshire & 25 & 29.35 & 1.49 & 3.66 & 50.60 & 16.19 \\
3/4 Duroc X 1/4 Landrace & 30 & 29.77 & 1.55 & 3.30 & 48.93 & 15.17 \\
Duroc & 29 & 29.88 & 1.27 & 4.05 & 53.48 & 16.74 \\
Yorkshire & 25 & 30.82 & 1.45 & 4.26 & 54.04 & 17.34 \\
\hline
\end{tabular}

${ }^{1}$ All differences were highly significant.

levels, the Yorkshires and the Durocs were significantly better in size of loin eye area than the Hampshires or the 3/4 Duroc X $1 / 4$ English Large Black Landrace line of pigs. Neither the first nor the last two were significantly different between each other.

The analysis of variance for the weight of the four primal cuts is presented in table 23. It showed a highly significant difference ascribable to breed. The difference favored the Yorkshires and the Durocs, between which there was no significant difference, as compared with the Hampshires and the $3 / 4$ Duroc X $1 / 4$ English Large Black Landrace barrows, which were also alike when the Duncan Multiple Test was used at the 1-percent level. When the comparison was made at the 5-percent level the difference was 
basically the same, except that the Hampshires and the $3 / 4$ Duroc $X 1 / 4$ English Large Black Landrace line were also significantly different.

The analysis of variance for the weight of the hams of the different

TABLE 21.-Analysis of variance for differences in carcass length among barrows of different breeds of swine

\begin{tabular}{c|r|r|r|c}
\hline Source of variation & D/F & S. S. & M. S. & F \\
\hline Breed & 3 & 29.0698 & 9.6899 & $6.06^{1}$ \\
Error & 105 & 167.7593 & 1.5977 & \\
\cline { 2 - 4 } Total & 108 & 196.8291 & & \\
\hline
\end{tabular}

${ }^{1}$ Significant at the 1-percent level.

Duncan Multiple Test:
At 1-percent level
Yorkshire
Duroc
3/4 Duroc- $1 / 4$ Landrace
Hampshire
30.82
29.88
29.77
29.35
At 5-percent level
Yorkshire
30.82

Duroc

29.88

3/4 Duroc- $1 / 4$ Landrace

29.77

Hampshire

29.35

TABLE 22.-Analysis of variance for differences among loin-eye area of the barrows of each breed of swine

\begin{tabular}{c|r|r|r|r}
\hline Source of variation & D/F & S. S. & M. S. & F \\
\cline { 1 - 3 } Breed & 3 & 15.0576 & 5.0192 & $16.05^{1}$ \\
Error & 105 & 32.8359 & .3127 & \\
\cline { 2 - 4 } Total & 108 & 47.8935 & & \\
\hline
\end{tabular}

${ }^{1}$ Significant at the 1-percent level.

Duncan Multiple Test:

At 1-percent level

\begin{tabular}{cccc} 
Yorkshire & Duroe & Hampshire & $3 / 4$ Duroc- $1 / 4$ Landrace \\
4.26 & 4.05 & 3.66 & 3.30 \\
\hline
\end{tabular}

At 5-percent level
Yorkshire
Duroc
4.26
4.05
Hampshire
3.66
$3 / 4$ Duroc- $1 / 4$ Landrace
3.30

breeds is presented in table 24 . There was a highly significant difference referable to breed. The Duncan Multiple Test either at the 1- or 5-percent level showed that the difference favored the Yorkshire breed as the best, with no difference between the Durocs or the Hampshires. The Station pigs 
TABLE 23.-Analysis of variance for differences among weights of the 4 principal cuts from different breeds of swine

\begin{tabular}{c|r|r|r|r}
\hline Source of variation & D/F & S. S. & M. S. & F \\
\cline { 1 - 2 } Breed & 3 & 489.0400 & 163.0133 & $18.34^{1}$ \\
Error & 105 & 933.1811 & 8.8874 & \\
\cline { 2 - 4 } Total & 108 & $1,422.2211$ & & \\
\hline
\end{tabular}

${ }^{1}$ Significant at the 1-percent level. Duncan Multiple Test:

At 1-percent level

Yorkshire 54.04

uroc

53.48

At 5-percent level

\begin{tabular}{cr} 
Yorkshire & $\begin{array}{c}\text { Duroc } \\
54.04\end{array}$ \\
\hline
\end{tabular}

Hampshire

50.60

Hampshire

50.60
3/4 Duroc- $1 / 4$ Landrace 48.93

TABLE 24.-Analysis of variance for differences among weight of the hams from swine of different breeds

\begin{tabular}{c|r|r|r|r}
\hline Source of variation & D/F & S. S. & M. S. & F \\
\cline { 1 - 2 } Breed & 3 & $\begin{array}{r}69.1829 \\
121.6502\end{array}$ & $\begin{array}{r}23.0610 \\
1.1586\end{array}$ & $19.90^{1}$ \\
Error & 105 & 190.8331 & & \\
\cline { 2 - 4 } Total & 108 & & \\
\hline
\end{tabular}

${ }^{1}$ Significant at the 1-percent level. Duncan Multiple Test:

At 1-percent level

Yorkshire

17.34

At 5-percent level

Yorkshire

17.34
Duroc

16.64

Duroc

16.64
Hampshire 16.19

Hampshire 16.19
3/4 Duroc- $1 / 4$ Landrace 15.17
3/4 Duroc- $1 / 4$ Landrace 48.93 
drace line of pigs, 24 litters of the Hampshire breed, and 20 of the Duroc breed. There was a significant difference in favor of the Yorkshire litters, but none among the other breeds.

Nevertheless, at 21 days of age, and at weaning time, the size of the Yorkshire litters was reduced considerably. There was no significant difference between the Yorkshire and the 3/4 Duroc X 1/4 English Large Black Landrace line litters, both of them being significantly superior to the other two breeds. There was no significant difference between the Hampshire or the Duroc litters.

A correlation analysis showed that the number of pigs in a litter greatly influences the total weight of the litter, as shown in table 5. In view of this a regression equation was worked out for the different age groups and the weights were corrected before analyzing the differences in weights per litter for each breed.

The analysis of variance for the total weight of litters at farrowing and at 21 days of age showed that there was no significant difference from breed at these stages. This was not the case at weaning. The litters of the $3 / 4$ Duroc X 1/4 English Large Black Landrace line were heavier at this time than any of the other breeds, but this difference in favor of the line was not statistically significant between the $3 / 4$ Duroc X 1/4 English Large Black Landrace pigs, and the Duroc and the Hampshire animals. The Yorkshire pigs were lighter than any of the other breeds at weaning time, and this difference was significant at the 5-percent level. At the 1-percent level, there was still no significant difference from breed among the Station animals, the Duroc, and the Hampshire; but the difference was significant between the Station pigs and the Yorkshire animals.

These results tend to show that, for some reason, the Yorkshire pigs slowed down in their growth after 21 days of age, or that the other pigs, especially those of the $3 / 4$ Duroc X $1 / 4$ English Large Black Landrace line, had a much better rate of growth during the later part of the lactation period.

\section{POSTWEANING PERFORMANCE}

\section{Rate of Gain}

The differences obtained in the rate of gain for the barrows were not significantly different from breed, although the $3 / 4$. Duroc X 1/4 English Large Black Landrace line had the highest average, followed by the Durocs, next the Yorkshire, and finally the Hampshire pigs.

There was a significant difference favoring the $3 / 4$ Duroc X $1 / 4$ English Large Black Landrace line when the gilts were compared. They were followed by the Duroc breed, next the Yorkshire, and last were the pigs of the 
Hampshire breed. No significant difference was found among boars, but the averages were higher for the Station line, followed by the Durocs, next were the Hampshires and finally, the lowest were the pigs of the Yorkshire breed.

\section{Feed Efficiency}

There was no significant difference between the $3 / 4$ Duroc X $1 / 4$ English Large Black Landrace line of pigs, the Yorkshires or the Durocs, when the gilts and the barrows were compared for efficiency of feed utilization. The Hampshires stood lowest of all breeds. This difference was significantly different from the other breeds. There was no significant difference attributable to breed in the boars.

\section{Back-fat Thickness}

The barrows of the Duroc breed had the lowest back-fat measurements of all. This difference was highly significant. There was no significant difference in this measurement among the barrows of the other three breeds.

Gilts of the Hampshire and the Yorkshire breeds had lower back-fat measurements than those of the other breeds. There was no significant difference among the females of the Duroc breed and those of the Station line.

There was no significant difference in this measurement among boars of the different breeds.

\section{Slaughtering Data}

The data thus far obtained showed no significant difference between breeds when the slaughtering and the carcass weights, as well as the dressing percentages of the carcasses were evaluated. This means that the animals of the different breeds were about the same weight when they were slaughtered, and that their carcasses dressed about the same percentage of their live weight.

The carcasses of the Yorkshire animals were the longest (significant at the 1-percent level). There was no significant difference among carcasses of the other three breeds.

In the loin-eye area and weight of the four primal cuts, the Yorkshire and Duroc pigs were superior to those of the other two breeds.

The weight of the ham of the Yorkshire pigs was superior to that of the other animals. No significant difference due to breed was found in weight of the ham of the Duroc and Hampshire pigs, but they were all above that of the Station pigs. 


\section{CONCLUSIONS}

The sows of the Yorkshire breed had the largest number of pigs per litter at farrowing, at 21, and at 56 days of age (weaning age). This superiority, though, was statistically significant above all the other breeds only at farrowing. For some reason the size of the litter was reduced at 21 days, and even more, by the time pigs were weaned. The same trend occurred in the size of litters of the other breeds, although it was less pronounced in the sows of the Station line. Therefore, the size of the litters of the Station line compared favorably with that of the Yorkshire pigs at such an important stage as weaning time. The sows of the Station line were able to wean a greater percentage of the pigs farrowed than were those of the other three breeds.

Since it is realized that size of litter has an influence on its total weight, weights were all corrected for this factor. An analysis of variance of the differences in corrected total weight of litters at farrowing and at 21 days of age indicated no significant difference from breed. At weaning time, although not statistically significant, the litters of the sows belonging to the line developed by the Station were heavier than those of the Duroc or Hampshire litters. Litters of the Yorkshire breeds were the higher at weaning time for all breeds and this difference was highly significant.

Therefore, as far as preweaning performance was concerned, the sows of the Station line and their progeny compared favorably with, or performed as well as those of the three imported breeds.

\section{BEHAVIOR OF ANIMALS}

There are also some observations to be made concerning some aspects of behavior of the sows from the imported breeds. The Hampshire sows were excessively nervous at farrowing time and could not be handled easily. The sows from these breeds were also the poorest as to percentage of pigs born that were weaned. Only 57 percent of pigs farrowed were weaned by these sows.

Sows of the Duroc breed had the fewest pigs farrowed per litter. They were able to wean only 66 percent of the pigs farrowed. Some sows had blind, or at least nonfunctional teats, and the number of teats was also small for some of them. These factors might have had something to do with the poor performance of the sows concerning number of pigs farrowed.

Concerning postweaning performance, there was no significant difference in rate of gain of the boars and barrows of the different breeds and the Station line. Among gilts, those of the Station breed were the fastest gainers, followed by the Duroc, then the Yorkshire, and last the Hampshire gilts. Nevertheless, there was no significant difference attributable to breed in 
the Station gilts, the Duroc, and the Yorkshire. The Hampshires were last, and this difference was significant as due to breed when compared with the gilts of the Station line.

There was no significant difference attributable to breed in feed efficiency when differences in the case of boars were analyzed. Barrows and gilts were fed together as a group and the feed-efficiency figures are an average for the whole group. In this the Yorkshires were the most efficient, followed by the Duroc pigs, the animals of the Station line, and the Hampshire pigs last. The difference attributed to breed in the first three breeds was not significant. The only significant difference was in the Hampshire pigs.

Based on this information it can be said that the $3 / 4$ Duroc X $1 / 4$ Landrace pigs performed as well in postweaning characteristics as the animals of the Yorkshire and Duroc breed and better than the Hampshires.

The slaughtering data presented in this work show that the $3 / 4$ Duros $X$ $1 / 4$ English Large Black line developed by the Station does not compare well with the animals of the imported breeds. In weight of hams, weight of the four principal cuts and loin area, the pigs of the Station line were always last in performance. These are very important characteristics and this shows that there is still much room for improvement in the Station pigs.

In conclusion, it can be said that the pigs of the line developed by the Station compared quite well with pigs from imported breeds, except in certain good meat characteristics.

It should be mentioned that, in no instance in this paper, do the authors mean to claim that the comparison was between imported breeds, or even representative animals of these breeds, and pigs from the line developed by the Station. The comparison was between pigs of the locally produced line and a few pigs of three imported breeds.

\section{SUMMARY}

The performance of the pigs of the $3 / 4$ Duroc X $1 / 4$ English Large Black Landrace line developed by the Station was compared with the performance of some imported animals. These imported pigs were from the Duroc, the Yorkshire, and the Hampshire breeds.

The comparison and the evaluation of the animals was based on preweaning and postweaning characters. The preweaning characters considered were the number of pigs at farrowing, the number at 21 days, and at weaning age. The rate of gain, the feed efficiency, the back-fat thickness corrected to 200 pounds, and carcass evaluation were considered as postweaning characters.

All the data obtained were submitted to analysis of variance and where the F values were significant, they were subjected to a Duncan Multiple Test to determine significance among the means. 
The overall evaluation of both preweaning and postweaning characters showed that the animals of the $3 / 4$. Duroc X $1 / 4$ English Large Black Landrace line of pigs were as good as any of the animals of the imported breeds with which they were compared, with the possible exception of the carcass evaluation, where the imported breeds gave somewhat better results. They were especially good in the number of pigs weaned, as well as in the weight at weaning time and in rate of gain.

\section{RESUMEN}

Se estudió el comportamiento de los cerdos de la línea $3 / 4$ Duroc X $1 / 4$ English Large Black Landrace en comparación con algunos cerdos importados. Los cerdos importados eran de las razas Duroc, Yorkshire y Hampshire.

La comparación se basó en los caracteres de producción antes y después del destete. En el primer caso se consideró el número de cerditos nacidos por lechigada, el número a los 21 días y al destete. Las características que se consideraron después del destete fueron: La tasa de ganancia, la eficiencia en la conversión de alimento a carne, la medida de grasa en la espalda de los cerdos corregida para un peso de 200 libras, y la evaluación de las canales de los cerdos castrados que se sacrificaron.

Todos los datos obtenidos se analizaron estadísticamente mediante un análisis de varianza. Cuando los valores $\mathrm{F}$ fueron significativos, se aplicó la prueba de Duncan para determinar las diferencias significativas entre los promedios.

La evaluación de todos estos datos demostró que los cerdos de la línea 3/4. Duroc X 1/4 English Large Black Landrace comparan favorablemente con los cerdos de las razas importadas con la posible excepción de las canales, en que los cerdos de las razas importadas fueron superiores. Los cerdos de la línea desarrollada por la Estación se distinguieron especialmente en cuanto al número de cerdos destetados por la lechigada, peso de la misma y tasa de ganancia diaria. 